\title{
Streptococcosis in aquarium fish
}

\author{
H. W. Ferguson, J. A. Morales, V. E. Ostland \\ Fish Pathology Laboratory, Department of Pathology, Ontario Veterinary College, University of Guelph, Guelph, Ontario, \\ Canada N1G 2W1
}

\begin{abstract}
Streptococcus-like bacteria were recovered in large numbers from moribund zebra danios Brachydanio rerio and pearl danios Brachydanio albolineatus imported into Canada as aquarium species. Histopathology revealed a bacteremia with lesions present in many organs, but in particular the spleen and kidney. These could best be characterized as acute and necrotizing rather than granulomatous. Similar disease was subsequently produced experimentally in zebra danios as well as in rainbow trout Oncorhynchus mykiss and white cloud mountain minnows Tanichthys albonubes, by means of bath immersion. In these experiments, mortality started 2 to $4 \mathrm{~d}$ after exposure.
\end{abstract}

KEY WORDS: Streptococcus B Bacteria $\cdot$ Histopathology Danios

\section{INTRODUCTION}

Streptococcosis is a septicemic disease that affects freshwater and marine fish, in both farmed and feral populations. In marine fish it has been reported worldwide in a variety of commercially important species including yellowtail Seriola spp. (Kimura \& Kusuda 1979), eels Anguilla japonica, menhaden Brevoortia patronus (Plumb et al. 1974, Cook \& Lofton 1975), striped mullet Mugil cephalus, bluefish Pomatomus saltatrix, and striped bass Morone saxatilis (Baya et al. 1990). Similarly in freshwater fish, Streptococcus sp. has been isolated from rainbow trout Oncorhynchus mykiss (Boomker et al. 1979, Kitao et al. 1981, Humphrey et al. 1987, Bragg et al. 1989), golden shiners Notemigonus crysoleucas (Robinson \& Meyer 1966), and tilapia Tilapia nilotica (Miyazaki et al. 1984).

Three groups of streptococci have been isolated from diseased fish: alpha-hemolytic, beta-hemolytic (Boomker et al. 1979, Kitao et al. 1981), and non-hemolytic (Plumb et al. 1974, Rasheed et al. 1985, Baya et al. 1990). Histopathologically, alpha-hemolytic streptococci usually caused granulomatous inflammation, for example in yellowtail and tilapia, whereas beta-hemolytic bacteria caused septicemia in ayu Plecoglossus altivelis and rainbow trout, and severe suppurative inflammation in the eyes of Japanese flounder Paralichthys olivaceus (Miyazaki et al. 1984). A gammahemolytic or non-hemolytic streptococcal infection in bullminnows Fundulus grandis caused a systemic infection that localized in the eye, liver and spleen (Rasheed et al. 1985). The taxonomic status of the fish pathogenic streptococci requires further clarification because the organism responsible for mortality in yellowtail and eels in Japan has recently been reclassified as a species of Enterococcus (Kusuda et al. 1991).

Streptococcosis is considered to be a serious economic problem in South Africa and Japan. In North America, non-hemolytic Group B streptococci were isolated from diseased golden shiners in freshwater. and from several species of feral marine fishes from the Gulf of Mexico (Robinson \& Meyer 1966, Plumb et al. 1974, Rasheed et al. 1985, Baya et al. 1990). Streptococcus sp. was also recovered from water and from tissue slurries that included the gastro-intestinal tract, of a small number of aquarium fish imported into North America from Southeast Asia (Trust \& Bartlett 1974, Shotts et al. 1975). To the best of our knowledge, however, there have been no reports of streptococcal infections associated with disease in aquarium fish in North America.

\section{HISTORY AND METHODS}

We recently observed a high mortality in zebra danios Brachydanio rerio Hamilton, 1822, and pearl danios Brachydanio albolineatus Blyth 1860, kept in a display aquarium along with clown loaches Botia mac- 
racanthus Bleeker 1852, neon tetras Paracheirodon innesi Myers 1936, plecostomus catfish Hypostomus punctatus Valenciennes 1840, and sucking loaches Gyrinocheilus aymonieri Tirant 1883. The fish were part of a consignment imported into Canada from breeding farms in the southern U.S. Water in the 5001 display aquarium was maintained at a temperature of $26^{\circ} \mathrm{C}$, and was recycled through an external biological filter. The fish were fed a commercial flake.

All fish initially appeared to be in good condition, and there was no clinical evidence of disease, but the zebra danios and pearl danios started to die in small numbers $1 \mathrm{wk}$ after introduction to the aquarium. Gross lesions were minimal except for hyperemia round the base of the pectoral fins (Fig. 1). After $6 \mathrm{wk}$, only 30 danios remained out of a population of 100 The other species in the aquarium were not affected.

Over the 6 wk of the outbreak, 15 fish $(7$ zebra danios and 8 pearl danios) that had recently died or were moribund were sampled for both bacteriology and histopathology. Aseptically taken swabs and smears from the peritoneal cavity and kidney were streaked onto trypticase soy agar (TSA; Difco), blood agar (TSA plus $5 \%$ citrated bovine blood) and MacConkey's agar (Difco). All plates were incubated at room temperature $(25$ $\pm 1^{\circ} \mathrm{C}$ ) for 48 to $72 \mathrm{~h}$. Smears were stained with Gram or Giemsa. For histopathology, fish were fixed whole in Bouin's solution for $24 \mathrm{~h}$ after slitting the abdomen to allow proper penetration of the fixative. The specimens were then transferred to $70 \%$ alcohol, sagittally sectioned, and routinely processed to paraffin wax. Sections $(5 \mu \mathrm{m})$ were cut and stained with hematoxylin and eosin (H\&E) and with Gram (Brown and Bren).

\section{Natural disease}

The findings from these first fish showed that they were suffering from a severe bacteremia. Smears from the abdominal cavity showed the presence of small Gram-positive cocci in pairs or chains (Fig. 2). Sections revealed the presence of a severe acute necrotizing reaction in many organs, but especially the spleen and kidney. Gram-stained sections showed that the changes corresponded with massive numbers of Gram-positive cocci (Fig. 3); large numbers of bacteria were also present within blood vessels throughout the fish. Axenic cultures of pinpoint non-hemolytic off-white colonies ( 1 to $2 \mathrm{~mm}$ in diameter) were recovered from all fish on TSA and blood agars, but not on Mac-
Conkey's agar. These isolates were catalase and oxidase negative, non-motile Gram-positive cocci, that occurred in pairs or short chains. They were tentatively identified as Streptococcus sp. (Table 1).

The preliminary results strongly suggested that this Streptococcus-like bacterium was the cause of the disease. Consequently, bacteriological and pathological studies were undertaken in order to further characterize the organism, to confirm its role in the etiology of the disease, and to investigate the susceptibility of other species of fish, in particular the susceptibility of rainbow trout, the species most widely farmed in Ontario.

\section{Experimental disease}

Species used for the experimental studies were zebra danios, white cloud mountain minnows Tanichthys albonubes Lin Shu-Yen 1932, and rainbow

Table 1 Characteristics of 7 presumptive Streptococcus isolates from zebra danios Brachydanio rerio. \pm : weak positive; BHIB: brain heart infusion broth

\begin{tabular}{|c|c|}
\hline Characteristic & Finding \\
\hline Gram reaction & + \\
\hline Cell shape & Cocci in pairs and chains \\
\hline Oxidase & - \\
\hline Catalase & - \\
\hline Motility & - \\
\hline$O / F$ reaction & $-1-$ \\
\hline TSI & $\mathrm{A} / \mathrm{A} \cdot \mathrm{H}_{2} \mathrm{~S}-$ \\
\hline Hemolysis (bovine blood) & - \\
\hline \multicolumn{2}{|l|}{ Growth at $\left({ }^{\circ} \mathrm{C}\right)$} \\
\hline 10,18 & - \\
\hline 25 & + \\
\hline 30 & \pm \\
\hline 37 & - \\
\hline \multicolumn{2}{|l|}{ Growth } \\
\hline $\mathrm{BHIB}+0 \% \mathrm{NaCl}$ & + \\
\hline $\mathrm{BHIB}+3 \% \mathrm{NaCl}$ & \pm \\
\hline $\mathrm{BHIB}+6.5 \% \mathrm{NaCl}$ & - \\
\hline BHIB $+10 \%$ bile salts & - \\
\hline BHIB, pH 9.6 & + \\
\hline MacConkey's & - \\
\hline Anaerobic growth (BBL GasPak) & + \\
\hline \multicolumn{2}{|l|}{ Hydrolysis of: } \\
\hline Casein, gelatin, esculin, hippurate & - \\
\hline \multicolumn{2}{|l|}{ Decarboxylates (Møller's) } \\
\hline Arginine & - \\
\hline Ornithine, lysine & + \\
\hline \multicolumn{2}{|l|}{ Acidification of carbohydrates: } \\
\hline Dextrose, mannose, sucrose & + \\
\hline $\begin{array}{l}\text { Arabinose, galactose, xylose, sorbitol, } \\
\text { lactose, maltose, salicin, raffinose, } \\
\text { inositol, trehalose, mannitol }\end{array}$ & - \\
\hline
\end{tabular}


trout. The temperature requirements for the bacterium (best at $25^{\circ} \mathrm{C}$ ) dictated the temperature at which the fish were held, even though this was high for the rainbow trout. Accordingly, all fish were maintained at room temperature $\left(25 \pm 1^{\circ} \mathrm{C}\right)$ in individual $30 \mathrm{l}$ glass aquaria; the water from each tank was aerated and recirculated through aquarium corner filters.

Several colonies of the original pearl danio isolate were inoculated into $1 \mathrm{l}$ of brain-heart infusion broth (BHIB, Difco) and grown at $25^{\circ} \mathrm{C}$ for $48 \mathrm{~h}$ on a rotary shaker $(200 \mathrm{rpm})$. A $50 \mathrm{ml}$ portion of the broth was then added to $450 \mathrm{ml}$ of sterile phosphate-buffered saline (PBS, $\mathrm{pH} 7.4$ ) and each group of fish was netted out and placed in a separate freshly prepared bacterial suspension $\left(3 \times 10^{7} \mathrm{CFU} \mathrm{ml}^{-1}\right)$ for $5 \mathrm{~min}$. Following exposure, both bath-challenged and control (uninoculated BHIB) groups were rinsed in $500 \mathrm{ml}$ of sterile PBS for $20 \mathrm{~s}$ before being returned to their respective aquaria.

Fish were observed daily for the appearance of clinical signs of disease. Recently dead or moribund fish were dissected, and aseptically taken swabs from the peritoneal cavity and kidney were streaked onto bovine blood agar and MacConkey's agar, and incubated at room temperature $\left(25 \pm 1^{\circ} \mathrm{C}\right)$ for 24 to $72 \mathrm{~h}$. For histopathological studies the fish were processed as before

\section{RESULTS}

The mortality and bacteriology data for each species are summarized in Table 2. Nine out of 16 exposed rainbow trout died, with mortality starting $3 \mathrm{~d}$ postexposure. Streptococcus-like bacteria were recovered from all 8 fish, in pure culture from 7 fish. External lesions were seen in only 2 trout: both fish exhibited exophthalmos, while 1 also had intra-ocular and periorbital hemorrhage (Fig. 4). Internally, all fish had splenomegaly to varying degrees, while the liver was yellow and had sub-capsular petechial hemorrhages. Histologically, the overall response was primarily one of hemorrhage and neutrophil exudation, plus bactere- mia and occasional thrombosis; large numbers of coccoid bacteria were easily seen in most blood vessels, especially in the capillary beds of the gills, cranial meninges, retina, and choroidal rete. Tissue changes targeted the spleen, which showed congestion and fibrinoid necrosis of the ellipsoidal sheaths with loss of reticular macrophages. Bacteria were widely scattered throughout the parenchyma of the spleen, but were also present within macrophages. Bacteria were present within the lamina propria of the intestinal tract, but the mucosa itself remained largely unaffected.

Fifteen out of 16 exposed danios died, 10 at 2 d postexposure, with no clinical signs. External lesions were visible in most fish, and were identical to those seen in the naturally occurring disease; they comprised pronounced congestion and hemorrhage around the base of the pectoral fins and over the heart. Seven of these fish were examined bacteriologically, and Streptococcus-like bacteria were recovered from them all; in 3 fish they were in pure culture. Histopathological lesions were similar to those described for the trout, except that in addition to the splenic lesions, there was severe congestion of the renal parenchyma, and pronounced degeneration and necrosis of many tubules. Large numbers of bacteria were present in the pericardial area, especially within the hemorrhagic musculature associated with the pectoral girdle.

All 10 exposed white cloud mountain minnows died, starting at Day 2 and ending at Day 4 post-exposure. There were no gross lesions, and no evidence of clinical disease. Streptococcus-like bacteria were recovered in pure culture from all 6 fish examined bacteriologically. Histopathological lesions were similar to those seen in the zebra danios.

In the control groups, none of the zebra danios and none of the white cloud mountain minnows died; 6 of the 8 control rainbow trout died, but streptococci were not isolated from these fish, and there were no pathological lesions suggesting a reason for the deaths. The water temperature was fairly high for these fish however, and it was felt that inadequate acclimation at this

Table 2. Mortality and bacterial recovery data for fish exposed for $5 \mathrm{~min}$ to Streptococcus-like bacterium

\begin{tabular}{|c|c|c|c|c|c|c|c|c|c|}
\hline \multirow[t]{2}{*}{ Species } & \multirow[t]{2}{*}{ Challenged } & \multicolumn{6}{|c|}{ Days to death } & \multirow[t]{2}{*}{ Mortality } & \multirow{2}{*}{$\begin{array}{l}\text { Bacterial } \\
\text { recovery }\end{array}$} \\
\hline & & 1 & 2 & 3 & 4 & 5 & 6 & & \\
\hline \multirow[t]{2}{*}{ Brachydanio rerio } & Yes 16 & 0 & 10 & 4 & 1 & 0 & 0 & $15 / 16$ & $7 / 7$ \\
\hline & No 16 & 0 & 0 & 0 & 0 & 0 & 0 & $0 / 16$ & $0 / 7$ \\
\hline \multirow[t]{2}{*}{ Tanichthys albonubes } & Yes 10 & 0 & 2 & 5 & 3 & 0 & 0 & $10 / 10$ & $6 / 6$ \\
\hline & No 10 & 0 & 0 & 0 & 0 & 0 & 0 & $0 / 10$ & $0 / 6$ \\
\hline \multirow[t]{2}{*}{ Oncorhynchus mykiss } & Yes 16 & 0 & 0 & 4 & 3 & 2 & 0 & $9 / 16$ & $8 / 8$ \\
\hline & No 8 & 4 & 1 & 0 & 1 & 0 & 0 & $6 / 8$ & $0 / 8$ \\
\hline
\end{tabular}




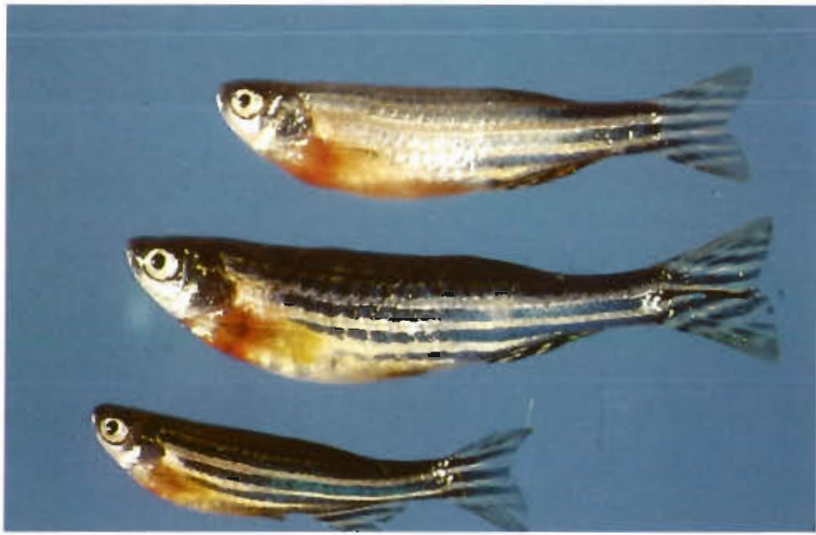

Fig. 1. Brachydanio rerio. Zebra danios with a naturally occurring Streptococcus infection shuwiny pronounced hyperemia at the base of the pectoral fins

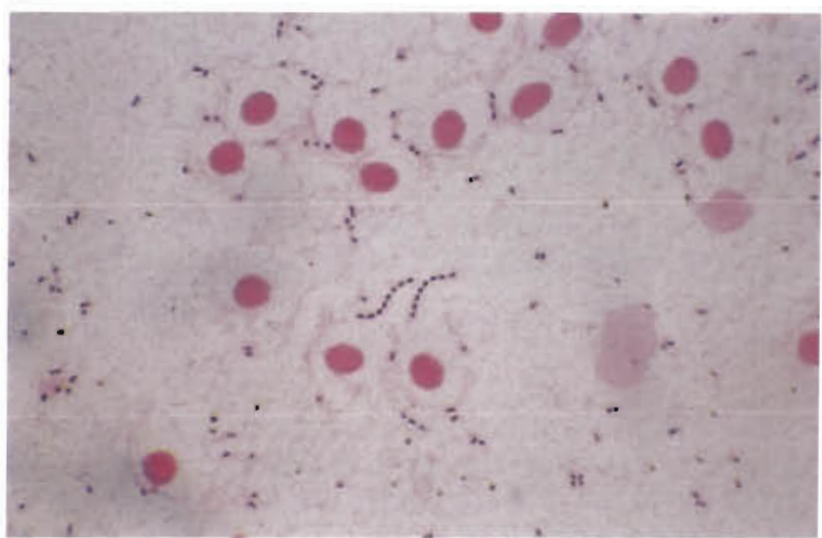

Fig. 2. Brachydanio rerio. Gram-stained smear from the peritoneal cavity of a zebra danio with Streptococcus infection showing numerous cocci. Two chains of the bacteria can be seen in the center. The nuclei of several erythrocytes may also be seen

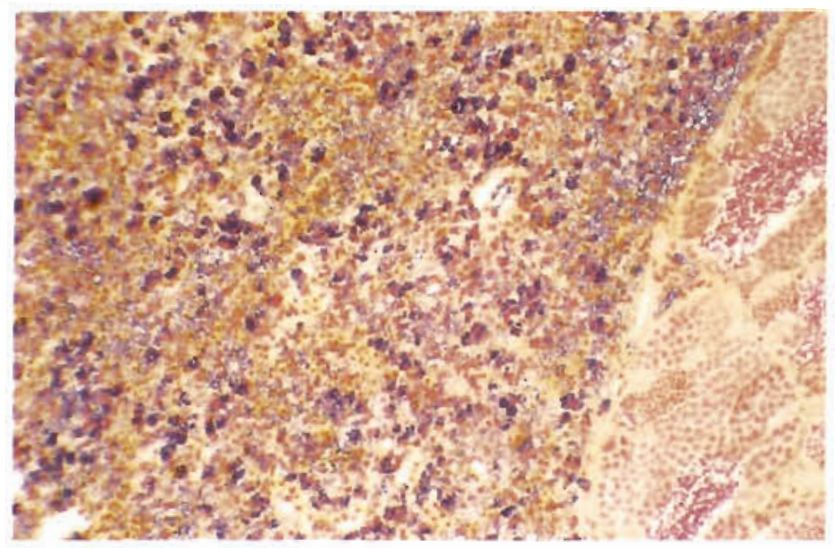

Fig. 3. Brachydanio rerio. Brown and Brenn Gram-stained section of a zebra danio with naturally occurring Streptococcus infection, showing massive numbers of Gram-positive bacteria within the parenchyma of the spleen

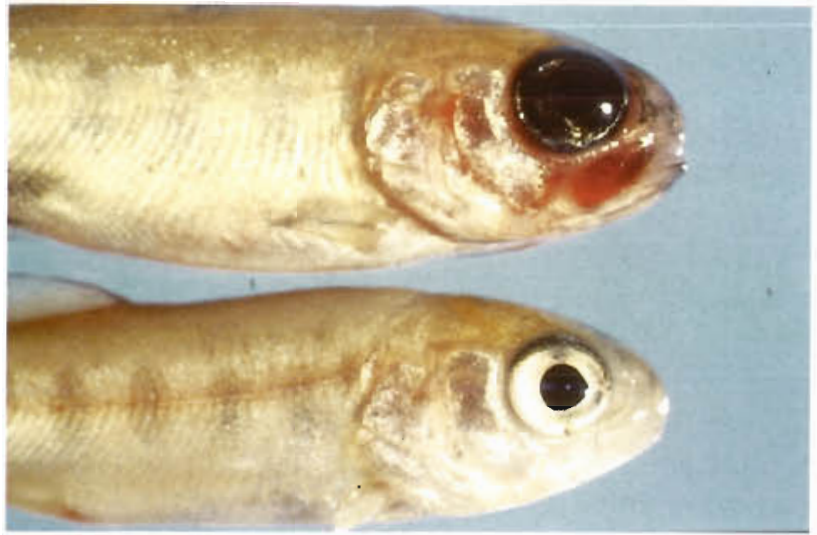

Fig. 4. Oncorhynchus mykiss. Experimentally produced Streptococcus infection in rainbow trout; the top tish has peri-orbital and intra-ocular hemorrhage

relatively high temperature for rainbow trout was the most probable reason for the mortality.

\section{DISCUSSION}

Although the results are clearly preliminary, it seems reasonable to suggest that the Streptococcus-like bacteria were the cause of mortality in the original outbreak. The appearance of the fish in the subsequent experimental infections was strikingly similar to the naturally occurring outbreak. Some of the interesting aspects of the disease include the ease with which the fish became infected, and the speed with which they subsequently died ( 2 to $4 \mathrm{~d}$ ). In most of the previous reports on Streptococcus sp. infections in a variety of species of fish, including rainbow trout, disease was produced only following injection (either i.p. or i.m.). Alternatively, when the bacteria were placed in the water, mortality was produced only in fish subjected to some traumatic insult (Rasheed \& Plumb 1984). By contrast, infection and mortality after $2 \mathrm{~d}$ were easily reproduced in golden shiners following bath exposure (Robinson \& Meyer 1966). Moreover, disease and mortality, starting within $3 d$, were easily transmitted by placing an infected golden shiner into an aquarium of healthy fish. These findings, therefore, closely parallel our own, and they serve to underline the extremely infectious and pathogenic nature of this organism.

The route of infection must remain a matter for speculation (Rasheed \& Plumb 1984), but the gills and/or the gastro-intestinal tract would seem to be reasonable suggestions. The presence of concurrent bacterial gill disease has been noted in Tasmania and Hungary, in rainbow trout and common carp respectively ( $\mathrm{J}$. Carson pers. comm.), and such an association could point to either stress-associated recrudescence in a 
carrier state, or to direct mucosal damage promoting gill infection. Nevertheless, we saw little evidence in our fish to suggest that any other pathogen was involved in the initiation or progression of the naturally occurring or the experimentally induced disease.

The physiological and biochemical characteristics of the non-hemolytic Streptococcus-like isolates recovered in this study did not allow us to place them within a well-defined group of streptococci. All were non-motile, non-spore-forming, non-fermentative, oxidase and catalase negative, Gram-positive cocci (in pairs and short chains) that failed to grow in $6.5 \% \mathrm{NaCl}$ and $10 \%$ bile salts, but did grow at pH 9.6. Many of the rather 'atypical' physiological and biochemical characteristics of our isolates were similar to those previously described for other fish-pathogenic streptococci from the U.S. (Wilkinson et al. 1973, Baya et al. 1990). Both our isolates and those of Baya et al. (1990) were not identifiable using the API 20S strips (Analytab Products, St. Laurent, Quebec, Canada) but gas chromatographic analysis of the cell wall fatty acid content of one of our isolates gave a pattern consistent with that of Streptococcus sp. (pers, obs.). Serological typing (Lancefield grouping) might have helped to establish the relationship of our isolates to other fish-pathogenic streptococci, but this may not necessarily be an appropriate characteristic to use for identification of some streptococci, because the criterion was originally used for identifying beta-hemolytic strains, and because many alpha-hemolytic and non-hemolytic isolates do not possess group-specific antigens (Schleifer \& Kilpper-Balz 1987).

The taxonomic relationship among fish pathogenic streptococci is poorly understood especially their relationship to other well-defined species within the genus. Physiological and DNA-rRNA hybridization studies have confirmed that the traditional streptococcal groups can be subdivided into 4 distinct groups with enterococci, lactococci, and anaerobic streptococci apparently showing no specific genetic relationship to any of the streptococcal species (Schleifer \& Klipper-Balz 1987). This taxonomic distinction has been confirmed among a group of fish-pathogenic 'streptococci' recovered from diseased yellowtail and eel in Japan, which warranted their reclassification as a new species of Enterococcus (Kusuda et al. 1991). A comprehensive taxonomic study of the fish-pathogenic streptococci is badly needed, especially genomic relationships which would help to identify taxonomically significant phenotypic markers, as well as help to define standardized laboratory methodologies, so that diagnosticians and researchers can identify their streptococcal isolates

In the present study, the pathological changes in the experimental fish closely paralleled those seen in the naturally occurring outbreak, and they were similar to those previously reported in other species for the septicemic, non-granulomatous form of the disease. The targeting of the spleen and kidney for the major lesions is consistent with the high bacterial-trapping capabilities of these organs (Ferguson et al. 1982). Peri-orbital and intra-ocular hemorrhage with exophthalmos were features of the naturally occurring disease in rainbow trout (Boomker et al. 1979, Humphrey et al. 1987); although we saw this lesion in only 2 fish, it nevertheless underlines the importance of the choroid rete in embolic disease. The presence of small thrombi in a few fish suggests the possibility of death due to disseminated intravascular coagulation, although much more work needs to be done to confirm this.

The source of the infection must also remain a matter for speculation. We do not know whether the recently imported fish carried the bacteria or whether the stress of transport rendered them susceptible to infection from an organism already present in the aquarium. We have no information about the disease history on the farm of origin, but with such a highly infectious organism it is hard to imagine that their stocks would have been healthy, if indeed the Streptococcus-like bacterium was already present. It is interesting to note that there are no disease control regulations that apply when importing aquarium fish into Canada, even though, as we have demonstrated, indigenous species such as the economically important rainbow trout may also be susceptible to pathogens that can affect both.

Acknowledgements. The Fish Pathology Laboratory receives much of its funding from the Ontario Ministry of Agriculture and Food. This study was initiated while J.A.M. was in Guelph on a Canadian International Development Agency (CIDA)-funded exchange visit from the School of Veterinary Medicine, Universidad Nacional, Heredia, Costa Rica, where he is permanently based

\section{LITERATURE CITED}

Baya, A. M., Lupiani, B., Hetrick, F. M., Roberson, B. S., Lukacovic, R., May, E., Poukish, C. (1990). Association of Streptococcus sp. with fish mortalities in Chesapeake Bay and its tributaries. J. Fish Dis. 13: 251-253

Boomker, J., Imes, G. D. Jr, Cameron, C. M., Naude, T. W., Schoonbee, H. J. (1979). Trout mortalities as a result of Streptococcus infection. Ond. J. vet. Res. 46: 71-77

Bragg, R. R., Oosthuizen, J. H., Lordan, S. M. (1989). The leech Batracobdelloides tricarinata (Blanchard, 1897) (Hirudinea: Glossiphoniidae) as a possible reservoir of the rainbow trout pathogenic Streptococcus species. Ond. J. vet. Res. 56: 203-204

Cook, D. W., Lofton, S. R. (1975). Pathogenicity studies with a Streptococcus sp. isolated from fishes in an AlabamaFlorida fish kill. Trans. Am. Fish. Soc. 2: 286-288

Ferguson, H. W., Claxton, M. J., Moccia, R. D., Wilkie, E. J (1982). The quantitative clearance of bacteria from the 
bloodstream of rainbow trout (Salmo gairdneri). Vet. Pathol. 19: 687-699

Humphrey, J. D., Lancaster, C. E., Gudkovs, N., Copland, J. W. (1987). The disease status of Australian salmonids. bacteria and bacterial diseases. J. Fish Dis. 10: 403-410

Kimura, H., Kusuda, R. (1979). Studies on the pathogenesis of streptococcal infection in cultured yellowtails Seriola spp.: effect of cell free culture on experimental streptococcal infection. J. Fish Dis. 2: $501-510$

Kitao, T., Aoki, T., Sakoh, R. (1981). Epizootic caused by betahaemolytic Streptococcus species in cultured freshwater fish. Fish Pathol. 15: 301-307

Kusuda, R., Kawai, K., Salati, F., Banner, C. R., Fryer, J. L. (1991). Enterococcus seriolicida sp. nov., a fish pathogen. Int. J. system. Bacteriol. 41: 06-409

Miyazaki, T., Kubota, S. S., Kaige, N., Miyashita, T. (1984). A histopathological study of streptococcal disease in tilapia. Fish Pathol. 19: 167-172

PIumb, I A , Schachte, J. H., Gaines, J. L., Peltiex, W., Carroll, B. (1974). Streptococcus sp. from marine fishes along the Alabama and northwest Florida coast of the Gulf of Mexico. Trans. Am. Fish. Soc. 2: 358-361.

Rasheed, V., Limsuwan, C., Plumb, J. (1985). Histopathology

Responsible Subject Editor: T. P. T. Evelyn, Nanaimo,

B.C., Canada of bullminnows, Fundulus grandis Baird and Girard, infected with a non-haemolytic group B Streptococcus sp. J. Fish Dis. 8: 65-74

Rasheed, V., Plumb, J. A. (1984). Pathogenicity of a nonhaemolytic group B Streptococcus sp. in gulf killfish (Fundulus grandis Baird and Girard). Aquaculture 37: $97-105$

Robinson, J. A., Meyer, F. P. (1966). Streptococcal fish pathogen. J. Bacteriol. 92: 512

Schleiffer, K. H., Kilpper-Balz, R. (1987). Molecular and chemotaxonomic approaches to the classification of streptococci, enterococci, and lactococci: a review. System. appl. Microbiol. 10: 1-29

Shotts, E. B, Klechner, A. L., Gratzek, J. B., Blue, J. L. (1975). Bacterial flora of aquarium fishes and their shipping waters imported from Southeast Asia. J. Fish. Res. Bd Can. 33: $732-735$

Trust, T. J., Bartlett, K. H. (1974). Occurrence of potential pathogens in water containing urndmentai fishes. Appi. Microbiol. 28: 35-40

Wilkinson, H. W., Thacker, L. G., Facklam, R. R. (1973). Nonhemolytic group B streptococci of human, bovine, and ichthyic origin. Infect. Immun. 7: 496-498

Manuscript first received: May 15, 1993

Revised version accepted: December 8, 1993 